\title{
The Pancreas: Causes for Malabsorption
}

\author{
Thilo Hackert $^{\mathrm{a}} \quad$ Kerstin Schütte $^{\mathrm{b}} \quad$ Peter Malfertheiner $^{\mathrm{b}}$ \\ ${ }^{a}$ Department of General Surgery, University of Heidelberg, \\ ${ }^{\mathrm{b}}$ Department of Gastroenterology, Hepatology and Infectious Diseases, Otto von Guericke University of Magdeburg, Germany
}

\section{Keywords}

Exocrine pancreatic insufficiency - Chronic pancreatitis . Pancreatic cancer - Pancreatic maldigestion .

Pancreatic resection

\section{Summary}

Background: The pancreas has a central function in digestion and glucose homeostasis. With regard to the exocrine function, which is responsible for the digestion and absorption of nutrients and vitamins, the most important disturbances of these physiological processes are based on deficiencies in enzyme production and secretion, either due to impaired excretion caused by obstruction of the pancreatic duct or due to loss of pancreatic tissue. Both conditions result in maldigestion, malabsorption, and malnutrition. Methods: Systematic literature review. Results: Symptoms associated with pancreatic exocrine failure are gastrointestinal discomfort, steatorrhea, and weight loss. Pancreatic exocrine insufficiency caused by ductal obstruction occurs in chronic pancreatitis or with neoplasia of the pancreatic head. Loss of functional parenchyma can be caused either by chronic pancreatitis resulting in fibrotic replacement of the destroyed parenchyma or by a postoperative state of pancreatic resection. Conclusion: In patients with chronic pancreatitis, a stage-adapted and timely therapy including conservative as well as surgical measures is essential to prevent functional deterioration and to preserve residual function. In the case of pancreatic resection for chronic pancreatitis, this can be achieved with modern organ-sparing surgery such as the duodenumpreserving pancreatic head resection. In patients requiring more extended pancreatic resections and even total duodenopancreatectomy, regardless of the underlying indication, adequate enzyme replacement and monitoring of the nutritional status is critical to prevent impairment of quality of life as well as detrimental malnutrition in the long term.

\author{
Schlüsselwörter \\ Exokrine Pankreasinsuffizienz - Chronische Pankreatitis . \\ Pankreaskarzinom - Pankreatische Maldigestion . \\ Pankreasresektion
}

\section{Zusammenfassung}

Hintergrund: Das Pankreas spielt für die Verdauung und für die Erhaltung der Glukose-Homöostase eine zentrale Rolle. Störungen in der Enzymproduktion und -sekretion, entweder durch eine Obstruktion des Pankreasgangs oder durch den Verlust funktionellen Gewebes, verursachen eine exokrine Pankreasinsuffizienz, die im Endstadium in Maldigestion, Malabsorption und Malnutrition mit Mangel an (fettlöslichen) Vitaminen und Spurenelementen resultiert. Methoden: Systematische Literaturübersicht. Ergebnisse: Die führenden klinischen Symptome der exokrinen Pankreasinsuffizienz sind abdominelle Beschwerden, Steatorrhö und Gewichtsverlust. Obstruktive Ursachen einer exokrinen Pankreasinsuffizienz können Tumoren im Pankreaskopfbereich oder eine chronische Pankreatitis sein, während ein Mangel an funktionellem Pankreasgewebe sowohl die Folge einer chronischen Pankreatitis als auch einer resezierenden Operation am Pankreas unabhängig von der Indikation sein kann. Schlussfolgerung: Bei Patienten mit chronischer Pankreatitis ist eine stadienadaptierte und rechtzeitige konservative Therapie, die bei Bedarf um chirurgische therapeutische Maßnahmen ergänzt wird, essenziell, um die Organfunktion zu erhalten. Bei Patienten mit chronischer Pankreatitis kann dies durch moderne, gewebesparende chirurgische Verfahren wie der duodenumerhaltenden Pankreaskopfresektion erreicht werden. Insbesondere bei Patienten mit ausgedehnteren Resektionen gleich welcher Indikation, bis hin zur Duodenopankreatektomie, sind die postoperative Pankreasenzymtherapie und ein Monitoring des Ernährungsstatus von besonderer Bedeutung, um eine Mangelernährung und eine Verschlechterung der Lebensqualität infolge einer solchen Operation zu verhindern.

\begin{tabular}{ll}
\hline KARGER & @ 2014 S. Karger GmbH, Freiburg \\
1662-6664/14/0303-0190\$39.50/0 \\
$\begin{array}{l}\text { Fax +49 761 452 07 14 } \\
\text { Information@Karger.com } \\
\text { www.karger.com }\end{array}$ & $\begin{array}{l}\text { Accessible online at: } \\
\text { www.karger.com/vim }\end{array}$
\end{tabular}

Prof. Dr. med. Peter Malfertheiner

Department of Gastroenterology, Hepatology and Infectious Diseases

Otto von Guericke University of Magdeburg

Leipziger Straße 44, 39120 Magdeburg, Germany

peter.malfertheiner@med.ovgu.de 


\section{Introduction}

The pancreas has a central function in digestion as well as control of glucose homeostasis. During the cephalic and gastric phase pancreatic enzyme secretion is mainly stimulated by vagal und neural reflexes. Acidic chymus mixed with nutrients entering the duodenum in the intestinal phase is the most important stimulus of pancreatic secretion mediated by cholecystokinin and secretin. These hormones exert a negative feedback on gastrin and thus on gastric acid production and motility of the stomach and duodenum [1]. In combination with the pancreatic bicarbonate secretion this results in a neutralization of gastric acid with duodenal alkalization which is crucial for pancreatic enzymes to work optimally.

In the interdigestive phase, pancreatic secretion is tightly coordinated with the migrating motor complex (MMC), and bursts of enzyme and bicarbonate secretion occur in association with MMC phase III every 80-120 min.

In the interdigestive phase, bicarbonate secretion amounts to approximately $25 \%$ of the maximum secretion during the postprandial phase, and the maximal pancreatic enzyme secretion is approximately $10 \%$ of the maximal digestive secretion.

The physiological role of the interdigestive pancreatic secretion (complemented by bile secretion) is thought of as a housekeeper cleaning the small bowel from bacterial overgrowth and other detrimental collections within the luminal site. Obviously, both the digestive and interdigestive functions of the exocrine pancreas as well as the pancreatic hormone production are heavily affected by inflammatory and neoplastic pancreatic diseases and the treatment of these.

A reduction in pancreatic enzyme activity in the intestinal lumen to a level that is below the threshold required to maintain normal digestion defines pancreatic exocrine insufficiency (PEI) [2]. Not only impaired pancreatic secretion but also extrapancreatic mechanisms can contribute to the manifestation of PEI and pancreatic maldigestion (table 1).

Primary pancreatic maldigestion of carbohydrate, protein, and fat is caused by decreased activity of amylase, trypsin, and lipase. The clinical picture of PEI is dominated by the consequences of deficient lipase activity resulting in steatorrhea which becomes apparent when pancreatic lipase output is reduced to $5-10 \%$ of its normal output [3]. Weight loss, bloating, abdominal discomfort, and complications of malnutrition (e.g. deficiency in lipid-soluble vitamins with consequences such as osteoporosis) are other clinical manifestations of pancreatic maldigestion.

This review gives an overview on current concepts of the diagnosis and treatment of pancreatic maldigestion with a focus on its most frequent causes, i.e. chronic pancreatitis and pancreatic cancer.

\section{Pathophysiology of Chronic Pancreatitis}

Chronic pancreatitis (CP) is characterized as a chronic inflammatory damage of the pancreas caused by various factors, most commonly long-lasting alcohol consumption (most often accompanied with smoking), but also genetic alterations, autoimmune affections, anatomical variations (pancreas divisum), or other rare causes [4]. The leading clinical symptom is pain, associated with symptoms caused by exocrine insufficiency with steatorrhea, intolerance of fatty food, and weight loss. Furthermore, endocrine failure and malignant transformation are possible manifestations of end-stage $\mathrm{CP}$ [4]. The functional failures in terms of exocrine and endocrine insufficiencies reflect the continuous destructive process during $\mathrm{CP}$ with fibrotic tissue replacement and intraductal calcifications mostly combined with obstruction of the pancreatic and/or bile duct resulting in excretory stasis and consecutive intestinal lack of pancreatic enzymes (and bile fluid in the case of cholestasis) (fig. 1).

Cell necrosis and apoptosis following inflammation lead to destruction of the excretory parenchyma. Pancreatic stellate cells play a key role in the mediation of fibrosis and the creation of a pronounced extracellular matrix. This matrix is not only evident in the interstitial spaces but also replaces tissue after the destruction of acinar cells [5]. The histomorphological architecture is severely altered, with an irreversible deformation of acinar, ductal, and islet structures [5]. Multiple cytokines and growth factors, which are mainly released from inflammatory cells and macrophages as well as endothelial cells, are involved in this process. In addition, a direct toxicity of alcohol and its metabolites is suggested to lead to direct activation of local fibroblast cells.

The generation of pain as the leading symptom in CP is complex with several diverse underlying mechanisms. It is generally accepted that pancreatic ductal hypertension and

Table 1. Pancreatic and extrapancreatic mechanisms of pancreatic maldigestion $[2,65]$

Loss of functioning parenchyma

Chronic pancreatitis

Cystic fibrosis

Pancreatic tumors

Pancreatic resection

Status post necrotizing acute pancreatitis

Diabetes mellitus (?)

Decreased secretion despite intact parenchyma

Pancreatic duct obstruction (e.g. tumor)

Decreased stimulation from the intestine (e.g. celiac disease,

Crohn's disease)

Decreased activity in the intestinal lumen

Postcibal asynchrony (e.g. gastric resection)

Short bowel syndrome

Inactivation of pancreatic enzymes (e.g. Zollinger-Ellison syndrome) 


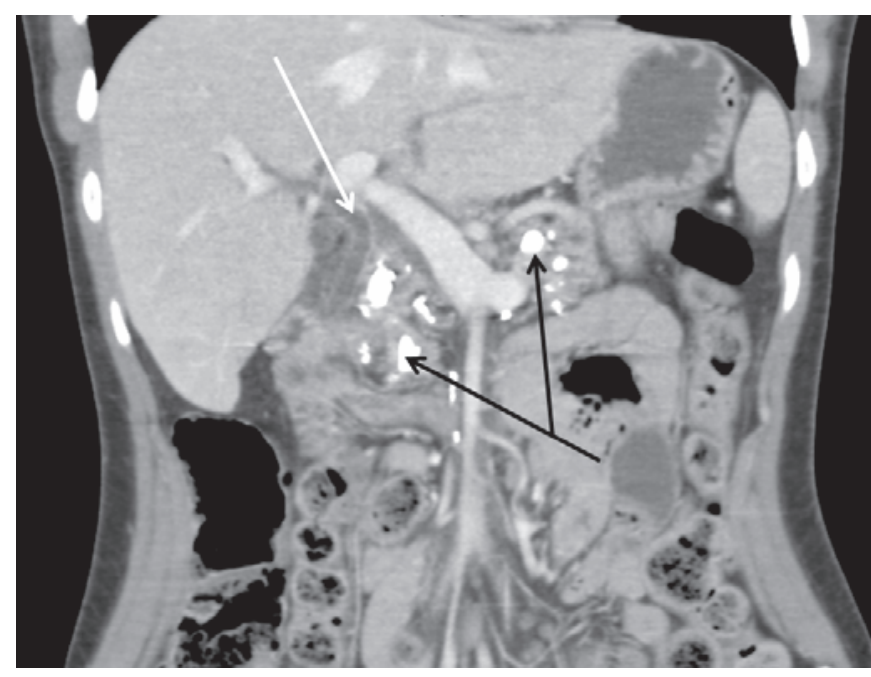

Fig. 1. Typical CT finding in advanced chronic pancreatitis. Extensive calcifications (black arrows) and consecutive dilation of the bile duct (white arrow).

perineural inflammation are the two main mechanisms of pain generation in CP. Pain is an early symptom in CP patients who show an increasing tendency towards stimulus-independent pain generation in the long term [6]. One of the most important pathophysiological concepts of $\mathrm{CP}$ is the concept of neuroimmunological inflammation [7]. This implies an interaction of immunological changes and neural modulations that lead to a reactive change in nerve diameter, density, and function with the consequence of a growing pain intensity in the long course of CP [8]. The intense pain character is understood not only as a result of morphological changes but also as an increasing stimulus-independent pain sensation showing characteristics of an autonomous pain generation due to a neural plasticity and memory function of the peripheral and central nervous system (CNS) that may develop over time $[9,10]$. The neural dysregulation consists of a hyperexcitability of dorsal root neurons combined with a decreased descending inhibition. This leads to an alteration in gut sensitivity and 'viscerotomes' as corresponding projection areas that are represented in the CNS. Irreversible changes in the brain with cortical reorganization contribute to stimulus-independent neuropathic pain in $\mathrm{CP}$ [9]. As these changes might be observed early in $\mathrm{CP}$, it is critically important to interrupt this cycle of pain generation and chronification as early as possible [11].

\section{Medical Therapy of Chronic Pancreatitis}

The aim of medical treatment is to relieve acute or chronic pain, prevent disease progression, prevent acute pain attacks, correct metabolic consequences (e.g. diabetes, malnutrition), address psychosocial problems, and manage complications when they arise [12]. In alcoholic CP, stopping alcohol intake and nicotine abuse are principal steps in its management.

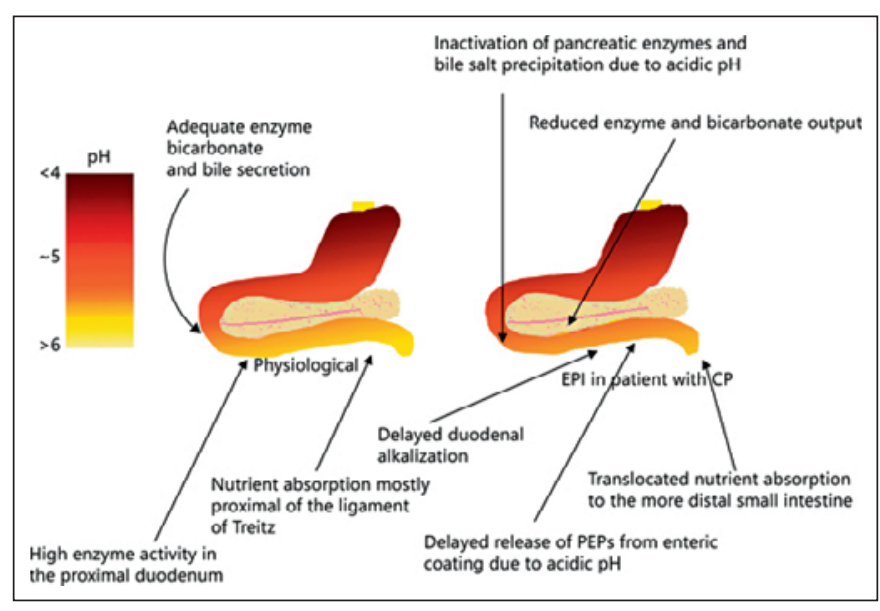

Fig. 2. Digestive pattern shifted to more distal parts of the small intestine in pancreatic insufficiency (adapted from [20]; copyright S. Karger AG, Basel).

In PEI, adequate oral substitution of pancreatic enzyme preparations (PEPs) is mandatory. The general requirements for PEPs are high lipase activity, resistance to gastric acid provided by enteric coating, homogenous mixing with the nutritional components, gastric emptying coordinated with nutrients, and early activation in the duodenum. Different compositions and galenic forms have been developed and tested with variable results. When comparing study data, the evolution of galenics, especially with respect to particle size and coating, has to be considered.

A fat-restricting diet to treat steatorrhea is not advocated any more. As patients with $\mathrm{CP}$ frequently present with a reduced body mass index (BMI) because of maldigestion and reduced food intake to avoid abdominal pain, a sufficient calorie intake as part of a diet adjusted to the individual patient's needs (e.g. diabetes mellitus) is recommended. The dose of PEPs, however, is adjusted to the fat intake of the patient with 2,000 IU of lipase per gram of fat ingested [13]. The recommended dose ranges from 25,000 to 75,000 units of lipase, depending on the fat content of the meal, and should be taken during the meal for optimal treatment effect [14]. Dietary advice on healthy nutrition combined with proper enzyme use provides the best results [15]. In the case of therapy failure in PEI, the first step in treatment recommendations is to increase the dosage [13]. Overdosing or intoxication with PEPs is impossible since the luminal enzymes are not absorbed. In patients with cystic fibrosis though, a dose-dependent risk of fibrotic colon stenosis has been described when using entericcoated PEPs [16]. Even in countries with well-organized health care systems most patients with PEI due to CP are insufficiently treated [17].

The prescription of proton pump inhibitors (PPI) in addition to an enteric-coated PEP is often necessary as an auxiliary agent if a PEP alone is not effective and a dose augmentation 
of the PEP dose does not lead to a satisfying improvement of symptoms (fig. 2) [18-20]. The success of PEP therapy should primarily be judged by the improvement of clinical symptoms (gain of weight, improvement of abdominal symptoms).

Although discussed controversially, a meta-analysis of published studies showed no significant effect of PEPs on pain in $\mathrm{CP}$ but an improvement of abnormal motility associated with $\mathrm{CP}$ leading to a reduction of postprandial dyspeptic symptoms [21, 22].

A deficiency in fat-soluble vitamins, especially vitamin $\mathrm{E}$, but also vitamin $\mathrm{A}$ and $\mathrm{D}$, is a frequent complication of $\mathrm{CP}$ and is observed in the clinical chemistry of up to $75 \%$ of patients with CP [23]. Approximately $25 \%$ of patients with CP present with osteoporosis [24]. Monitoring and therapy should be performed according to current guidelines.

In the case of persistent alcohol abuse, a possible deficiency in vitamin $\mathrm{B}_{1}, \mathrm{~B}_{2}$, and $\mathrm{B}_{6}$ should also be replaced.

Therapy of pain, which is frequently the leading clinical symptom in patients with $\mathrm{CP}$, shows a significant variability between individual patients and therefore needs to be characterized diligently concerning character, intensity, frequency, and possible causes. Current World Health Organization (WHO) recommendations for analgetic therapy following a multi-step scheme should be followed [25], starting with peripheral analgetics (e.g. acetaminophen, non-steroidal analgetics) supported by adjuvant therapy that can be escalated by the addition of mild opioids (e.g. tramadol) or high potent opioids.

Therapy of endocrine pancreatic insufficiency mainly follows the rules for treatment of diabetes mellitus type 1 with absolute insulin deficiency; however, metformin is recommended as first-line therapy of diabetes mellitus type $3 \mathrm{c}$ as it reduces the risk of pancreatic cancer [26]. In most cases an additional therapy with insulin is unavoidable. As patients with pancreatogenic diabetes are at an increased risk of hypoglycemia and also frequently not reliable with respect to compliance, simple insulin regimens are preferable. The avoidance of hypoglycemic complications is one of the most important aims.

\section{Surgical Therapy of Chronic Pancreatitis}

Surgical therapy of CP mainly includes two approaches: draining procedures or resection of the chronically inflamed parenchyma. Drainage without resection offers the benefit of maximal preservation of parenchyma with, at least theoretically, maintenance of all residual endo- and exocrine functions. In these procedures, however, the remaining fibrotic tissue may be responsible for ongoing clinical problems. Besides, the hypothetical functional benefit of full tissue preservation has to be seen according to the aspect that this tissue has been subjected to long-lasting inflammation with loss of function, bearing furthermore an increased risk of malignant transformation. Therefore, resection procedures have gained more and more acceptance during the last decade.
In the majority of $\mathrm{CP}$ patients, pathological changes are focused on the head of the pancreas with an inflammatory mass and/or calcifications and a subsequent stenosis of the pancreatic and/or bile duct [27]. The surgical approach in the majority of CP patients is therefore any type of pancreatic head resection. Partial duodenopancreatectomy has been regarded as the primary surgical procedure in this situation for many years. However, these resections are unsatisfactory in terms of late morbidity with an incidence of up to $50 \%$ of postoperative diabetes mellitus as well as an impaired exocrine function with steatorrhea and inability of gaining weight in 30$60 \%$ of the patients [28].

Today, duodenum-preserving pancreatic head resection (DPPHR), which was introduced in the 1970s [29], is considered the standard procedure for non-malignant head lesions in CP [30]. Several modifications of DPPHR have been developed and can be used depending on the extent of the calcifications, fibrosis, and duct dilation. The Berne modification as the most tissue-sparing approach offers a limited head resection with wide drainage of the pancreatic and, if necessary, bile duct into the resection cavity [31].

All fibrotic and calcified pancreatic head tissue should be removed and the pancreatic duct has to be opened to extract stones and ensure free drainage from the left into the resection cavity. Special attention has to be paid to the bile duct. In the case of preoperative cholestasis and/or preceding stents, the bile duct needs to be opened widely and the orifice should be fixed in the resection cavity to avoid postoperative recurrence of bile duct stenosis. The intestinal drainage of pancreatic and bile fluid is restored by a retrocolic side-to-side pancreaticojejunostomy with a Roux-en-Y jejunal loop. The DPPHR procedures are widely accepted nowadays and have been shown to be equally efficient as the Whipple procedure regarding long-term pain relief, overall morbidity and mortality combined with significantly less intraoperative blood replacement, shorter hospital stay, more postoperative weight gain, less exocrine insufficiency, better occupational rehabilitation, and quality of life [32-34]. As the methodological quality of these studies, especially with regard to long-term outcome, is not sufficient for defining the best type of pancreatic head resection in $\mathrm{CP}$ based on level I evidence, current randomized controlled trials are in progress [35].

More rarely the pancreatic body and tail are the cause for the symptoms of CP. In these cases, fibrosis, calcifications, and pseudocysts are the most important findings while small duct disease is rather rare. According to the localization of fibrosis or calcifications, distal pancreatectomy can be performed. In the case of a localized pathology, middle segmental pancreatectomy is used as another parenchyma-sparing procedure [36]. The segment of altered tissue can afterwards be resected with a stapler or hand-sewn closure towards the head. The distal stump of the pancreas is mobilized and reconstruction is accomplished with a pancreaticojejunostomy 
and Roux-en-Y anastomosis. Fistula rates between 8 and $63 \%$ are reported for middle pancreatic resection, which is explained by the different underlying pathologies, with lowest rates achieved in CP patients [37, 38].

Surgical pseudocyst drainage is a procedure performed less frequently for symptomatic pseudocysts (most frequently pain and gastrointestinal discomfort caused by compression of the stomach, duodenum, or proximal small bowel) as well as for complicated cysts due to rupture or bleeding. Usually, cysts with a diameter $<5 \mathrm{~cm}$ rarely cause symptoms or complications. While today most pseudocysts can be managed successfully by endoscopy, those with bleeding or hematoma need to be approached surgically. Furthermore, patients with unsuccessful preceding endoscopic or interventional pseudocyst therapy should undergo surgical management with a cystojejunostomy to create the draining site at the most caudal point of the cyst. In most patients, the cyst is extending towards the transverse mesocolon, which offers the possibility of a transmesocolic approach with a side-to-side cystojejunostomy and Roux-en-Y reconstruction.

In contrast to the $\mathrm{CP}$ procedures described above, all patients with suspected malignancy have to undergo oncological surgical procedures identical to those in pancreatic cancer, and limited parenchyma-sparing approaches are not adequate.

\section{Pancreatic Ductal Adenocarcinoma}

Pancreatic adenocarcinoma is the fourth leading cause of cancer-related death in Germany in men and women. The clinical presentation is heterogeneous, depending on tumor localization within the organ and tumor stage. While in early cancer stages (suitable for curative treatment) the disease is frequently asymptomatic, pain, jaundice, loss of appetite, and weight loss are the most frequent symptoms in advanced tumor stages [39].

Symptoms are frequently reported to be initially intermittent and therefore lead to a late diagnostic work-up [40].

The characteristic perineural infiltration of pancreatic adenocarcinoma is causative for pain, presenting either as back pain or as epigastric pain radiating to the back. Partial or complete obstruction of the pancreatic duct may lead to postprandial aggravation of pain. In up to $3 \%$ of the patients, pancreatic adenocarcinoma initially presents with acute pancreatitis due to either pancreatic duct obstruction or diffuse infiltration of the organ [41]. Most pancreatic adenocarcinomas are localized in the pancreatic head and cause obstructive jaundice due to an infiltration of the common bile duct in up to $80 \%$ of the patients.

Diabetes mellitus is not only associated with an increased risk for pancreatic adenocarcinoma but also with a possible clinical manifestation of the malignant disease [42, 43].

More than $80 \%$ of patients with pancreatic cancer present with weight loss at the time of diagnosis [39]. Several etiologic factors, including anorexia, cachexia, and maldigestion, contribute to this symptom. Cancer cachexia, defined as an unintended weight loss of more than $10 \%$ within 6 months, is a significant factor influencing quality of life and survival [44, 45]. Different cytokines including TNF- $\alpha$, IFN- $\gamma$, and interleukins 1 and 6 are involved in this process. Sarcopenia (skeletal muscle wasting) is a clinically important phenomenon [46]. Additional PEI is a sequel of local destruction of healthy pancreatic tissue, which is aggravated by possible obstruction of the main pancreatic duct in the case of tumors being located in the pancreatic head.

\section{Surgery for Pancreatic Tumors}

Pancreatic tumors, especially ductal adenocarcinoma, as well as cystic lesions such as intraductal papillary mucinous neoplasm (IPMN) generally require more extended resections than $\mathrm{CP}$ as oncological aspects must be considered. Limited resections such as enucleations or segmental pancreatectomy are restricted to small neuroendocrine tumors (NET) or branch-duct IPMN without confirmed malignancy. Criteria for resectability in pancreatic malignancies are absent metastases (liver/peritoneum) and no evident involvement of the central arterial vessels (celiac trunk, superior mesenteric artery). In the latter case, a neoadjuvant treatment is initiated with the aim of a secondary resection. Portal and mesenteric vein involvement as well as involvement of adjacent organs are not regarded as a general contraindication but require more extended surgical approaches.

The standard approach towards pancreatic head tumors is the pylorus-preserving partial duodenopancreatectomy [47]. Currently, approximately $90 \%$ of all head resections are performed with a preservation of the pylorus; a classical Whipple procedure is limited to situations with tumor spread towards the pylorus, suspicious lymph nodes in this area, or an anamnesis of gastric ulcers. Partial duodenopancreatectomy can be combined with venous resection of the porto-mesenterico axis, if necessary, which leads to comparable results regarding oncological outcome and quality of life [48]. Adjacent organs, if affected by the tumor, can also be removed when a radical resection is achieved. These multivisceral procedures show an increased morbidity but also good oncological results [49]. In contrast, arterial tumor infiltration should be considered as a general contraindication for surgical therapy as arterial resections in pancreatic cancer are associated not only with an increased morbidity and mortality but also with poor oncological results [50]. In addition, postoperative quality of life is often limited due to long-lasting diarrhea and symptoms of malabsorption, which is generally understood as a consequence of extended removal of the autonomic intestinal innervation along the arteries. For the same reason, no extended lymphadenectomy should be performed during partial duodenopancreatectomy. 
Table 2. Functional long-term outcome after surgical therapy of chronic pancreatitis; duodenum-preserving pancreatic head resection (DPPHR) versus partial duodenopancreatectomy (DP)

\begin{tabular}{|c|c|c|c|c|c|c|c|}
\hline \multirow[t]{2}{*}{ Author } & \multirow{2}{*}{$\begin{array}{l}\text { Patients, } \\
\text { DPPHR/ } \\
\text { DP }\end{array}$} & \multirow[t]{2}{*}{ Follow-up ${ }^{a}$} & \multicolumn{5}{|l|}{ DPPHR/DP } \\
\hline & & & $\begin{array}{l}\text { mortality, n } \\
(\%)\end{array}$ & $\begin{array}{l}\text { morbidity, } \\
\%\end{array}$ & $\begin{array}{l}\text { pain release, } \\
\%\end{array}$ & $\begin{array}{l}\text { endocrine } \\
\text { insufficiency, \% }\end{array}$ & $\begin{array}{l}\text { exocrine } \\
\text { insufficiency }\end{array}$ \\
\hline Büchler et al., 1995 [66] & $20 / 20$ & 6 months & $0 / 0$ & - & $75 / 33$ & - & - \\
\hline Farkas et al., 2006 [67] & $20 / 20$ & 1 year & $0 / 0$ & $0 / 40$ & $85 / 90$ & - & $25 / 55$ \\
\hline Izbicki et al., 1995 [34] & $31 / 30$ & 1.5 years & $1(3.2) / 0$ & $19 / 53$ & $90 / 87$ & $0 / 10$ & $7 / 58$ \\
\hline Klempa et al., 1995 [33] & $22 / 21$ & $3-5$ years & $1(5) / 0$ & $18 / 29$ & $75 / 33$ & $12 / 38$ & $10 / 100$ \\
\hline Keck et al., 2012 [68] & $42 / 43$ & $>5$ years & $0 / 0$ & $33 / 30$ & $67 / 67$ & $45 / 44$ & $76 / 63$ \\
\hline Zheng et al., 2012 [69] & $66 / 57$ & 6 years & $0 / 0$ & $3 / 19$ & $84 / 81$ & $15 / 32$ & $17 / 28$ \\
\hline Strate et al., 2008 [70] & $24 / 23$ & 7 years & $6(15) / 4(15)$ & - & b & $57 / 65$ & $86 / 96$ \\
\hline Müller et al., 2008 [71] & $15 / 14$ & 14 years & $5(25) / 5(25)$ & - & b & $42 / 77$ & $47 / 43$ \\
\hline Bachmann et al., 2013 [72] & $32 / 32$ & 15 years & $30 / 53$ & - & $22 / 19$ & $81 / 86$ & $86 / 93$ \\
\hline
\end{tabular}

${ }^{\text {a}}$ Follow-up 6-12 months (upper part of table), follow-up 5-15 years (lower part of table).

${ }^{\text {b}}$ Frequency and intensity of pain not significant between both groups.

Standard lymphadenectomy includes the lymph nodes of the hepatoduodenal ligament, along the common hepatic artery, the portal and cranial portion of the superior mesenteric vein, as well as right-sided lymph nodes of the celiac trunk and along the right side of the superior mesenteric artery [47]. The impact of extended lymph node dissection (i.e. in the interaortocaval space, left-sided of the celiac trunk and superior mesenteric artery) has been well investigated in randomized controlled trials between 1998 and 2005 without showing any difference in survival [51-53]. Extended lymphadenectomy mainly showed adverse effects with a significantly increased surgical morbidity and decreased quality of life in the postoperative follow-up [51-53].

For malignancies of the body and tail of the pancreas, distal pancreatectomy is performed in combination with splenectomy to achieve a radical resection and a sufficient extent of lymphadenectomy. Lymph node dissection during distal pancreatectomy includes the lymph nodes in the hepatoduodenal ligament along the celiac trunk and the left side of the superior mesenteric artery $[54,55]$. As lymphatic and autonomous nerve tissue on the right side of the mesenteric axis is preserved, functional intestinal complications as described before with diarrhea and malabsorption are rarely observed in the postoperative course. However, new-onset diabetes mellitus seems to be more frequent, possibly explained by the pronounced location of the islet cells in the body and tail of the pancreas [55].

Total duodenopancreatectomy is required for tumors located in the central part of the gland and, recently increasing, for extended main-duct IPMNs [56, 57]. Basically, it is a combination of the two procedures described above and is therefore also associated with an extended lymphadenectomy and removal of autonomous nerval tissue. Regarding these aspects, the functional postoperative deficiencies are most evident after this procedure and severe disturbances of oral food tolerance as well as absorption of nutrients, vitamins, and trace elements combined with brittle diabetes mellitus are possible in the postoperative course. These changes require an intense supervision and education of these patients as described below.

\section{Postoperative Care and Outcome}

After formal or extended pancreas resections, the gastric tube is routinely removed at the end of the operation and oral intake of the patients is allowed, beginning on the first postoperative day with fluid and quickly increasing every day until completion on day 4-5 postoperatively. Standard medication includes PPI and pancreatic enzymes as soon as oral intake of solid food is started. Usually, the enzyme dosage is 20,000 40,000 IU per meal; however, it can be increased in the case of maldigestion, diarrhea, and abdominal discomfort. In the case of partial pancreas resections, enzymes may be discontinued in the long-term follow-up, depending on the remaining exocrine function of the individual patient. According to series in the literature, life-long enzyme supplementation is needed in approximately $70 \%$; without enzyme intake, steatorrhea as the leading symptom of exocrine failure is observed in up to $60 \%$ of the patients [58]. Under optimal dosage of pancreatic enzymes, more than $90 \%$ of the patients show normal stool function and regain their preoperative body weight $( \pm 5 \%)$ in the first postoperative year (table 2) [59].

Endocrine function following partial pancreatectomy is impaired in $15-20 \%$ of preoperatively non-diabetic patients, resulting in oral antidiabetics in approximately $10-15 \%$ and insulin dependency in 6-8\% [60].

Total pancreatectomy as the most invasive resection naturally leads to a deprivation of all pancreatic function and inevitably life-long enzyme and insulin therapy [56]. However, 
the quality of life of these patients has continuously improved due to both optimized nutritional care and diabetes therapy during the last decades [61].

\section{General Recommendations}

A multidisciplinary team including oncologists, surgeons, gastroenterologists, pathologists, radiologists, dietitians, pain managing experts, social workers, and psychooncologists for the treatment of patients with pancreatic cancer is desirable in any stage of the disease.

In addition to tumor-directed therapy (surgery and/or chemotherapy dependent on tumor stage), supportive therapy addressing tumor symptoms is mandatory. Optimal supply with a well-balanced diet is the basis of nutritional therapy.

Treatment of PEI and diabetes mellitus in patients with pancreatic cancer follows the same principles as in CP. If enzyme administration in combination with PPI is not sufficient to compensate PEI, additional diagnostic procedures to assess the degree of PEI and to rule out further causes of diarrhea and malabsorption (bacterial overgrowth, chologenic diarrhea) are mandatory [62].

Additional treatment options addressing cachexia are currently under evaluation but so far sufficient evidence from prospective clinical trials is lacking [46, 63, 64].

\section{Conclusion}

The pancreas as a central digestive gland can be the cause for malabsorption either due to genuine pancreatic diseases (chronic inflammation or neoplasia) or as a consequence of preceding resections. From the functional point of view, pancreatic bicarbonate secretion is mandatory for duodenal neutralization of gastric acid to enable pancreatic enzymes to work optimally. PEI is defined as a critically reduced intestinal pancreatic enzyme activity with clinical symptoms dominated by the consequences of deficient lipase activity resulting in steatorrhea, bloating, abdominal discomfort, weight loss, and complications of malnutrition (e.g. deficiency in lipid-soluble vitamins with consequences like osteoporosis).

In $\mathrm{CP}$, modern surgical options aim at the preservation of as much tissue as possible (e.g. duodenum-preserving head resections), while in neoplastic diseases, more extended resections are required (e.g. partial or total duodenopancreatectomy). Consequently, exocrine insufficiency in the postoperative situation frequently requires long-term enzyme supplementation and a close interdisciplinary patient care in order to avoid malnutrition-associated complications.

\section{Disclosure Statement}

Nothing to declare.

\section{References}

1 Verkijk M, Gielkens HA, Lamers CB, Masclee AA: Effect of gastrin on antroduodenal motility: role of intraluminal acidity. Am J Physiol 1998;275: G1209-1216.

2 Lindkvist B: Diagnosis and treatment of pancreatic exocrine insufficiency. World J Gastroenterol 2013; 19:7258-7266.

3 DiMagno EP, Go VL, Summerskill WH: Relations between pancreatic enzyme outputs and malabsorption in severe pancreatic insufficiency. N Engl J Med 1973;288:813-815.

4 Hoffmeister A, Mayerle J, Beglinger C, et al: S3Leitlinie Chronische Pankreatitis: Definition, Ätiologie, Diagnostik, konservative, interventionell endoskopische und operative Therapie der chronischen Pankreatitis. Leitlinie der Deutschen Gesellschaft für Verdauungs- und Stoffwechselkrankheiten (DGVS). Z Gastroenterol 2012;50:1176-1224.

5 Brock C, Nielsen LM, Lelic D, Drewes AM: Pathophysiology of chronic pancreatitis. World J Gastroenterol 2013;19:7231-7240.

6 Vardanyan M, Rilo HL: Pathogenesis of chronic pancreatitis-induced pain. Discov Med 2010;9:304310.

7 Friess H, Zhu ZW, di Mola FF, et al: Nerve growth factor and its high-affinity receptor in chronic pancreatitis. Ann Surg 1999;230:615-624.

8 Ceyhan GO, Bergmann F, Kadihasanoglu M, et al: Pancreatic neuropathy and neuropathic pain - a comprehensive pathomorphological study of 546 cases. Gastroenterology 2009;136:177-186.e1
-9 Drewes AM, Krarup AL, Detlefsen S, et al: Pain in chronic pancreatitis: the role of neuropathic pain mechanisms. Gut 2008;57:1616-1627.

10 Sakorafas GH, Tsiotou AG, Peros G: Mechanisms and natural history of pain in chronic pancreatitis: a surgical perspective. J Clin Gastroenterol 2007; 41:689-699.

11 Strobel O, Büchler MW, Werner J: Surgical therapy of chronic pancreatitis: indications, techniques and results. Int J Surg 2009;7:305-312.

12 Braganza JM, Lee SH, McCloy RF, McMahon MJ Chronic pancreatitis. Lancet 2011;377:1184-1197.

13 Sikkens EC, Cahen DL, Kuipers EJ, Bruno MJ: Pancreatic enzyme replacement therapy in chronic pancreatitis. Best Pract Res Clin Gastroenterol 2010;24:337-347.

14 Domínguez-Muñoz JE, Iglesias-García J, IglesiasRey M, et al: Effect of the administration schedule on the therapeutic efficacy of oral pancreatic enzyme supplements in patients with exocrine pancreatic insufficiency: a randomized, three-way crossover study. Aliment Pharmacol Ther 2005;21: 993-1000.

15 Rämö OJ, Puolakkainen PA, Seppälä K, Schröder TM: Self-administration of enzyme substitution in the treatment of exocrine pancreatic insufficiency. Scand J Gastroenterol 1989:24:688-692.

16 Smyth RL, van Velzen D, Smyth AR, et al: Strictures of ascending colon in cystic fibrosis and highstrength pancreatic enzymes. Lancet 1994;343:85-86.
17 Sikkens EC, Cahen DL, van Eijck C, et al: Patients with exocrine insufficiency due to chronic pancreatitis are undertreated: a Dutch national survey. Pancreatology 2012;12:71-73.

18 Layer P, Keller J: Lipase supplementation therapy: standards, alternatives, and perspectives. Pancreas 2003;26:1-7.

19 Böhm K, Teich N, Hoffmeister A, et al: Transforming growth factor-beta- 1 variants are not associated with chronic nonalcoholic pancreatitis. Pancreatology 2005;5:75-80.

20 Waldthaler A, Schütte K, Malfertheiner P: Role of acid suppression in exocrine pancreatic insufficiency: a therapeutic principle. Front Gastrointest Res 2013;32:84-91.

21 Brown A, Hughes M, Tenner S, Banks PA: Does pancreatic enzyme supplementation reduce pain in patients with chronic pancreatitis: a meta-analysis. Am J Gastroenterol 1997;92:2032-2035.

22 Garcés MC, Gómez-Cerezo J, Codoceo R, et al: Postprandial cholecystokinin response in patients with chronic pancreatitis in treatment with oral substitutive pancreatic enzymes. Dig Dis Sci 1998;43:562-566.

23 Duggan S, O'Sullivan M, Feehan S, et al: Nutrition treatment of deficiency and malnutrition in chronic pancreatitis: a review. Nutr Clin Pract 2010;25:362370.

24 Duggan SN, Smyth ND, Murphy A, et al: High prevalence of osteoporosis in patients with chronic pancreatitis: a systematic review and meta-analysis. Clin Gastroenterol Hepatol 2014;12:219-228. 
25 Cancer Pain Relief and Palliative Care. Report of a WHO Expert Committee. World Health Organ Tech Rep Ser 1990;804:1-75.

26 Cui Y, Andersen DK: Pancreatogenic diabetes: special considerations for management. Pancreatology 2011;11:279-294.

-27 Keck T, Marjanovic G, Fernandez-del Castillo C, et al: The inflammatory pancreatic head mass: significant differences in the anatomic pathology of German and American patients with chronic pancreatitis determine very different surgical strategies. Ann Surg 2009;249:105-110.

28 Sakorafas GH, Farnell MB, Nagorney DM, et al: Pancreatoduodenectomy for chronic pancreatitis: long-term results in 105 patients. Arch Surg 2000; 135:517-523; discussion 523-524.

29 Beger HG, Büchler M, Bittner RR, et al: Duodenum-preserving resection of the head of the pancreas in severe chronic pancreatitis. Early and late results. Ann Surg 1989;209:273-278.

-30 Diener MK, Rahbari NN, Fischer L, et al: Duodenum-preserving pancreatic head resection versus pancreatoduodenectomy for surgical treatment of chronic pancreatitis: a systematic review and metaanalysis. Ann Surg 2008;247:950-961.

31 Gloor B, Friess H, Uhl W, Büchler MW: A modified technique of the Beger and Frey procedure in patients with chronic pancreatitis. Dig Surg 2001; 18:21-25.

32 Berberat PO, Ingold H, Gulbinas A, et al: Fast track - different implications in pancreatic surgery. J Gastrointest Surg 2007;11:880-887.

33 Klempa I, Spatny M, Menzel J, et al: Pankreasfunktion und Lebensqualität nach Pankreaskopfresektion bei der chronischen Pankreatitis. Eine prospektive, randomisierte Vergleichsstudie nach duodenumerhaltender Pankreaskopfresektion versus Whipple'scher Operation. Chirurg 1995;66:350-359.

34 Izbicki JR, Bloechle C, Knoefel WT, et al: Duodenum-preserving resection of the head of the pancreas in chronic pancreatitis. A prospective, randomized trial. Ann Surg 1995;221:350-358.

35 Diener MK, Bruckner T, Contin P, et al: ChroPactrial: duodenum-preserving pancreatic head resection versus pancreatoduodenectomy for chronic pancreatitis. Trial protocol of a randomised controlled multicentre trial. Trials 2010;11:47.

36 Müller MW, Friess H, Kleeff J, et al: Middle segmental pancreatic resection: an option to treat benign pancreatic body lesions. Ann Surg 2006;244 909-918; discussion 918-920.

37 Bassi C: Middle segment pancreatectomy: a useful tool in the management of pancreatic neoplasms. J Gastrointest Surg 2007;11:726-729.

-38 Adham M, Giunippero A, Hervieu V, et al: Central pancreatectomy: single-center experience of 50 cases. Arch Surg 2008;143:175-180; discussion 180181.

39 Porta M, Fabregat X, Malats N, et al: Exocrine pancreatic cancer: symptoms at presentation and their relation to tumour site and stage. Clin Transl Oncol 2005;7:189-197.

40 Evans J, Chapple A, Salisbury H, et al: 'It can't be very important because it comes and goes' - patients' accounts of intermittent symptoms preceding a pancreatic cancer diagnosis: a qualitative study. BMJ Open 2014;4:e004215.

41 Lin A, Feller ER: Pancreatic carcinoma as a cause of unexplained pancreatitis: report of ten cases Ann Intern Med 1990;113:166-167.
42 Chari ST, Leibson CL, Rabe KG, et al: Probability of pancreatic cancer following diabetes: a population-based study. Gastroenterology 2005;129:504511.

43 Huxley R, Ansary-Moghaddam A, Berrington de González A, et al: Type-II diabetes and pancreatic cancer: a meta-analysis of 36 studies. Br J Cancer 2005;92:2076-2083.

44 Bachmann J, Ketterer K, Marsch C, et al: Pancreatic cancer related cachexia: influence on metabolism and correlation to weight loss and pulmonary function. BMC Cancer 2009;9:255.

45 Bachmann J, Büchler MW, Friess H, Martignoni ME: Cachexia in patients with chronic pancreatitis and pancreatic cancer: impact on survival and outcome. Nutr Cancer 2013;65:827-833.

46 Fearon, Kenneth $\mathrm{CH}$, Baracos VE: Cachexia in pancreatic cancer: new treatment options and measures of success. HPB (Oxford) 2010;12:323-324.

47 Adler G, Seufferlein T, Bischoff SC, et al: S3-Leitlinie 'Exokrines Pankreaskarzinom' 2007 - Ergebnis einer evidenzbasierten Konsensuskonferenz (13.-14.10.2006). Z Gastroenterol 2007;45:487-523.

48 Hackert T, Büchler MW, Werner J: Surgical options in the management of pancreatic cancer. Minerva Chir 2009;64:465-476.

49 Hartwig W, Hackert T, Hinz U, et al: Multivisceral resection for pancreatic malignancies: risk-analysis and long-term outcome. Ann Surg 2009;250:81-87.

50 Mollberg N, Rahbari NN, Koch M, et al: Arterial resection during pancreatectomy for pancreatic cancer: a systematic review and meta-analysis. Ann Surg 2011;254:882-893.

51 Pedrazzoli S, DiCarlo V, Dionigi R, et al: Standard versus extended lymphadenectomy associated with pancreatoduodenectomy in the surgical treatment of adenocarcinoma of the head of the pancreas: a multicenter, prospective, randomized study. Lymphadenectomy Study Group. Ann Surg 1998;228: 508-517.

52 Yeo CJ, Cameron JL, Sohn TA, et al: Pancreaticoduodenectomy with or without extended retroperitoneal lymphadenectomy for periampullary adenocarcinoma: comparison of morbidity and mortality and short-term outcome. Ann Surg 1999; 229:613-622; discussion 622-624.

53 Michalski CW, Kleeff J, Wente MN, et al: Systematic review and meta-analysis of standard and extended lymphadenectomy in pancreaticoduodenectomy for pancreatic cancer. Br J Surg 2007;94:265273

54 Johnson CD, Schwall G, Flechtenmacher J, Trede M: Resection for adenocarcinoma of the body and tail of the pancreas. Br J Surg 1993;80:1177-1179.

55 Brennan MF, Moccia RD, Klimstra D: Management of adenocarcinoma of the body and tail of the pancreas. Ann Surg 1996;223:506-511; discussion 511-512.

56 Büchler MW, Wagner M, Schmied BM, et al: Changes in morbidity after pancreatic resection: toward the end of completion pancreatectomy. Arch Surg 2003;138:1310-1314; discussion 1315.

57 Schmidt CM, Glant J, Winter JM, et al: Total pancreatectomy (R0 resection) improves survival over subtotal pancreatectomy in isolated neck margin positive pancreatic adenocarcinoma. Surgery 2007; 142:572-578; discussion 578-580.
58 Armstrong T, Walters E, Varshney S, Johnson CD: Deficiencies of micronutrients, altered bowel function, and quality of life during late follow-up after pancreaticoduodenectomy for malignancy. Pancreatology 2002;2:528-534.

59 Imamura N, Chijiiwa K, Ohuchida J, et al: Prospective randomized clinical trial of a change in gastric emptying and nutritional status after a pyloruspreserving pancreaticoduodenectomy: comparison between an antecolic and a vertical retrocolic duodenojejunostomy. HPB (Oxford) 2014;16:384-394.

60 Hackert T, Hinz U, Fritz S, et al: Enucleation in pancreatic surgery: indications, technique, and outcome compared to standard pancreatic resections. Langenbecks Arch Surg 2011;396:1197-1203.

61 Keck T, Hopt UT: Totale Pankreatektomie: Renaissance eines Operationsverfahrens. Chirurg 2008; 79:1134-1140.

62 Kahl S, Malfertheiner P: Exocrine and endocrine pancreatic insufficiency after pancreatic surgery. Best Pract Res Clin Gastroenterol 2004;18:947-955.

63 Bachmann J, Friess H, Martignoni ME: Molekulare Mechanismen und klinische Auswirkungen der Tumorkachexie. Z Gastroenterol 2008;46:1384-1392.

64 Kraft M, Kraft K, Gärtner S, et al: L-Carnitinesupplementation in advanced pancreatic cancer (CARPAN) - a randomized multicentre trial. Nutr J 2012;11:52.

65 Keller J, Layer P: Human pancreatic exocrine response to nutrients in health and disease. Gut 2005 54(suppl 6): vi1-28.

66 Büchler MW, Friess H, Müller MW, et al: Randomized trial of duodenum-preserving pancreatic head resection versus pylorus-preserving Whipple in chronic pancreatitis. Am J Surg 1995;169:65-69; discussion 69-70.

67 Farkas G, Leindler L, Daróczi M: Prospective randomised comparison of organ-preserving pancreatic head resection with pylorus-preserving pancreaticoduodenectomy. Langenbecks Arch Surg 2006;391:338-342.

68 Keck T, Adam U, Makowiec F, et al: Short- and long-term results of duodenum preservation versus resection for the management of chronic pancreatitis: a prospective, randomized study. Surgery 2012; 152(suppl 1):S95-S102.

69 Zheng Z, Xiang G, Tan C, et al: Pancreaticoduodenectomy versus duodenum-preserving pancreatic head resection for the treatment of chronic pancreatitis. Pancreas 2012;41:147-152.

70 Strate T, Bachmann K, Busch P, et al: Resection vs drainage in treatment of chronic pancreatitis: longterm results of a randomized trial. Gastroenterology 2008;134:1406-1411.

71 Müller MW, Friess H, Martin DJ, et al: Long-term follow-up of a randomized clinical trial comparing Beger with pylorus-preserving Whipple procedure for chronic pancreatitis. Br J Surg 2008;95:350-356.

72 Bachmann K, Tomkoetter L, Kutup A, et al: Is the Whipple procedure harmful for long-term outcome in treatment of chronic pancreatitis? 15-years follow-up comparing the outcome after pylorus-preserving pancreatoduodenectomy and Frey procedure in chronic pancreatitis. Ann Surg 2013;258: 815-820; discussion 820-821. 